\title{
Genetic gain in apomictic species of the genus Paspalum ${ }^{1}$
}

\author{
Emerson André Pereira ${ }^{2}$, Miguel Dall'Agnol ${ }^{2}$, Karla Médici Saraiva $^{2}$, Carine Simioni ${ }^{2}$, \\ Ana Paula Steiner Leães ${ }^{2}$, José Antonio Gonzalez da Silva ${ }^{3}$
}

10.1590/0034-737X201764010009

\begin{abstract}
The objective of this work was to provide means to obtain genetic gain in apomictic species of the genus Paspalum by identifying traits that simultaneously show high correlation and heritability. Thus, to determine the amount of phenotypic variation due to genetic and environmental effects and the degree of association between leaf dry matter production and other traits of forage interest that are easy to select and measure will bring agility and economy in the selection of forage species. The experiment was conducted in the years 2009/10 and 2010/11 in the municipalities of Eldorado do Sul and Augusto Pestana, RS, Brazil, in a randomized complete block design with three replicates. The increase in the direct selection pressure on total and leaf dry matter of apomictic accesses of the genus Paspalum is enhanced by a greater contribution of genetic effects than environmental effects on the composition of the phenotypic variance. Efficient genetic gain in leaf production is achieved by indirect selection of total dry matter, which is a trait of high heritability and easy to select and measure.
\end{abstract}

Key words: heritability; correlation; path analysis; plant breeding.

\section{RESUMO}

\section{A busca de ganho genético em espécies apomíticas do gênero Paspalum}

O objetivo do trabalho foi fornecer subsídios para obtenção de ganho genético em espécies apomíticas do gênero Paspalum pela identificação de caracteres que evidenciem simultaneamente alta correlação e herdabilidade. Assim, dimensionar o quanto da variação fenotípica é devido a efeitos genéticos e ambientais e o grau de associação existente entre a produção da matéria seca de folha como outros caracteres de interesse forrageiro de mais fácil seleção e aferição, proporcionará agilidade e economia no processo de seleção de plantas forrageiras. O experimento foi conduzido nos anos de 2009/10 e 2010/11 nos municípios de Eldorado do Sul e Augusto Pestana, RS, Brasil, em um delineamento experimental de blocos casualizados com três repetições. Nos acessos apomíticos do gênero Paspalum o aumento da pressão de seleção direta sobre a matéria seca total e de folhas é fortalecida pela maior contribuição dos efeitos genéticos do que ambientais sobre a composição da variância fenotípica. O ganho genético na produção de folhas se mostra eficiente via seleção indireta pela matéria seca total, caráter de elevada herdabilidade e de mais fácil seleção e aferição.

Palavras-chave: herdabilidade; correlação; análise de trilha; melhoramento vegetal.

\footnotetext{
Submitted on March 11 th, 2014 and accepted on November 23 ${ }^{\text {rd }}, 2016$.

${ }^{1}$ This work is part of the first author's thesis.

${ }^{2}$ Universidade Federal do Rio Grande do Sul, Departamento de Plantas Forrageiras e Agrometeorologia, Porto Alegre, Rio Grande do Sul, Brazil. emersonpijui@yahoo.com.br, migueld@ufrgs.br; karlamsaraiva@gmail.com; carine.simioni@ufrgs.br; ana_steiner@hotmail.com

${ }^{3}$ Universidade Regional do Noroeste do Estado do Rio Grande do Sul, Departamento de Estudos Agrários, Ijuí, Rio Grande do Sul, Brazil. jagsfaem@yahoo.com.br

*Corresponding author: emersonpijui@yahoo.com.br
}

Rev. Ceres, Viçosa, v. 64, n.1, p. 060-067, jan/fev, 2017 


\section{INTRODUCTION}

Edaphoclimatic conditions in the Southern Cone are favorable for high meat and milk yields, which generate the need to develop cultivars with great potential for producing quality forage. In these conditions, native species of the genus Paspalum have advantages over the exotic species because of the greater adaptation and great intra- and interspecific variability in forage-related traits (Pereira et al., 2012; Daurelio et al., 2014).

The genus Paspalum includes the largest number of native species and also those with the highest quality of animal feed (Nabinger et al., 2009; Aguilera et al., 2011). However, research that assists in selection strategies for the breeding of these species in Brazil is scarce. In addition, for being an apomictic species, the progeny is genetically identical to the parent plant, without the allelic recombination from the union of gametes that is essential in the development of new genotypes. On the other hand, when one of the parents presents sexual reproduction, there is the possibility of genetic variability, which may allow the recovery of elite progenies with the fixation of alleles in the first generation of self-fertilization due to the apomixis itself (Acuña et al., 2009; Valle et al., 2009).

A number of studies have been carried out to assist in obtaining genetic gain in the genera Brachiaria, Pennisetum, Trifolium, and others through breeding programs (Montardo et al., 2003; Silva et al., 2008; Borges et al., 2011), but in relation to the genus Paspalum, there are no reports of such studies in the literature. In this way, studies on heritability and correlation can provide more conclusive criteria on the selection pressure of a species, favoring the selection of genotypes with superior performance (Benin et al., 2009; Galarça et al., 2010). It is worth noting that, in forage species, selection is preferably performed directly on the trait of greater importance such as leaf production, for its high nutritional value and for being the plant part preferentially consumed by animals (Brâncio et al., 2003). However, the estimation of this character requires more time and labor due to the need for botanical separation.

The correlations that indicate beneficial association do not always show cause and effect with safety, compromising the benefits via indirect selection (Cruz et al., 2004). Therefore, path analysis comes up as a complementary technique indicating the true associations of cause and effect on the main variable of interest. This procedure aims to measure the true relationships such as in the components of grain yield of grain species (Lopez \& Franke, 2011; Krüger et al., 2011), as well as forage species (Silva et al., 2008; Borges et al., 2011).

The objective of this work was to provide means to obtain genetic gain in apomictic species of the genus
Paspalum by identifying traits that simultaneously show high correlation and heritability and, therefore, to measure how much of the phenotypic variation is due to genetic and environmental effects and the degree of association of leaf dry matter with other traits of forage interest that are easy to select and measure.

\section{MATERIAL AND METHODS}

The study was conducted in the years 2009/10 and 2010/11, in two locations. At the Agronomic Experimental Station (EEA) of the Agronomy College, UFRGS, in the municipality of Eldorado do Sul, RS, within the coordinates $30^{\circ} 06^{\prime} 02^{\prime \prime} \mathrm{S}$ and $51^{\circ} 41^{\prime} 27^{\prime \prime} \mathrm{W}, 34 \mathrm{~m}$ altitude. EEA is located in the Central Depression Region, climate type Cfa, humid subtropical with hot summer, according to the Köppen classification, and average annual rainfall of $1440 \mathrm{~mm}$. The soil is classified as typic Dystrophic Red Argisol (PVd) located in the São Jerônimo Mapping Unit (Streck et al, 2008), shallow with fine sand texture. The other location was at the Regional Rural Development Institute (IRDeR) of the Department of Agrarian Studies (DEAg), UNIJUÍ, in the municipality of Augusto Pestana, RS, within the coordinates $28^{\circ} 25^{\prime} 58^{\prime \prime} \mathrm{S}$ and $54^{\circ} 00^{\prime} 24^{\prime \prime} \mathrm{W}, 290 \mathrm{~m}$ altitude. IRDeR is located in the Middle Plateau Region, climate type Cfa, according to Köppen classification, and average annual rainfall of $1600 \mathrm{~mm}$. The soil is classified as typic dystroferric Red Latosol, dark red color, deep and clayey texture (Streck et al., 2008).

The experiment was arranged in a randomized block design with three replications in both locations. The experimental units consisted of plots with six rows of $2.20 \mathrm{~m}$ in length and $0.20 \mathrm{~m}$ apart. Plants in the rows were spaced $0.20 \mathrm{~m}$ apart, totaling 60 plants per plot. The following Paspalum accessions were used in the study: 28B, 26A, 28C, 26D and 28E of the species P. lepton and Azulão and Baio of $P$. guenoarum. These accessions were selected from a collection belonging to the Department of Forage Plants and Agrometeorology of UFRGS, which were collected from natural environments of Rio Grande do Sul. These accessions stood out, in preliminary studies, for greater forage production and for presenting nutritional and cytogenetic characteristics for use in breeding programs (Reis et al., 2008; Pereira et al., 2011).

The plants were cut when the leaves reached an average of $35 \mathrm{~cm}$ in height and remained with $10 \mathrm{~cm}$ from the soil. The variables measured were total dry matter (TDM, kg ha' ${ }^{1}$ ), leaf dry matter (LDM, $\mathrm{kg} \mathrm{ha}^{-1}$ ), culm dry matter (CDM, kg $\mathrm{ha}^{-1}$ ), leaf/culm ratio (LCR, $\mathrm{kg} \mathrm{kg}^{-1}$ ), harvest index ( $\mathrm{HI}, \mathrm{kg} \mathrm{kg}^{-}$ ${ }^{1}$ ), and tiller number (TIN, $\mathrm{m}^{-2}$ ) in each cut. Cuts were summed up for TDM, LDM and CDM. LCR and HI were obtained by dividing the mean productions in each year and location of LDM by CDM and LDM by TDM, respectively. 
Data were examined by analysis of variance per location to obtain the mean squared values of the genotypes in the mean of the years of cultivation, involving, overall, the cumulative effect of years and locations in the model. This procedure is recommended by Krüger et al. (2011) for ensuring consistency in the estimation of heritabilities and correlations. The mean square values were used to determine the genetic parameters, according to Carvalho et al. (2001). Following, the data were subjected to Pearson correction analysis to obtain the magnitude and direction of associations between the traits studied (Falconer \& Mackay, 1996). The significance of the correlations was tested by the $t$ test at $5 \%$ probability, according to Steel \& Torrie (1980), with n - 2 degrees of freedom, using the model

$t=r /[(1-r 2) /(n-2)] 0,5$

where $r$ is the correlation coefficient between the characters $\mathrm{X}$ and $\mathrm{Y}$ and $\mathrm{n}$ is the number of degrees of freedom at the considered levels.

Therefore, the analysis involved a total of $n=42$ [Eldorado do Sul (2009/10 + 2010/11 +7 apomictic accesses +3 replications)]; $\mathrm{n}=42$ [Augusto Pestana $(2009 / 10+$ 2010/1011 + 7 apomythic accesses +3 replications)]; and $\mathrm{n}=84$ [Overall (Eldorado do Sul + Augusto Pestana + $2009 / 10+2010 / 2011+7$ apomictic accesses +3 replications)]. Later, for biologically appropriate and safe interpretation, the degree of collinearity between the independent variables was verified (Coimbra et al., 2005). When there was a moderate to strong multicollinearity among the explanatory variables (based on the classification proposed by Montgomery \& Peck, 2001), a $\mathrm{k}$ value was obtained; a coefficient that seeks to remove the effects of multicollinearity in the model. From this point onwards, the correlations were unfolded through path analysis into estimates of the direct and indirect effects, considering leaf dry matter (LDM) as main dependent variable. Statistical analyzes were performed using the GENES program (Cruz, 2006).

\section{RESULTS AND DISCUSSION}

The treatment mean squares (TMS) showed significant differences among the apomictic genotypes evaluated in the two-year average in Eldorado do Sul, with the exception of TIN (Table 1). Values of TDM and LDM above six and four tons per hectare, respectively, stand out in this environment. The analysis of the genetic parameters showed a greater contribution of genetic than environmental effects to the expression of TDM and LDM due to the higher heritabilities (Table 1). On the other hand, CDM, LCR and HI indicated a reduced participation of gene effects, which suggests lower selection pressure in the recovery of the genotype with superior performance for these variables. There was lack of genetic variance for the trait TIN, indicating difficulty in obtaining genetic gain in the populations evaluated. Thus, the selection of superior plants from apomictic progenies derived from these genotypes requires greater variability in the trait TIN, mainly from the sexual female parent. In Augusto Pestana $(2009 / 10+2010 / 11)$, a greater participation of genetic effects was also observed in the composition of the phenotypic variance in the traits TDM and LDM. On the other hand, CDM showed intermediate heritability and LCR, HI and TIN showed a strong participation of the environmental variance (Table 1). This condition confirms that the selection pressure on LCR, HI and TIN in populations of clonal hybrids is strongly affected by the environment, indicating the need for greater experimental control to reduce the error in the identification of genetically promising plants.

In the overall analysis (cumulative effect of years and locations), the results confirm the greater facility of selection in these species using TDM and LDM due to the high heritabilities (Table 1). On the other hand, although CDM and LCR indicate intermediate values, their estimates are more difficult because they involve leaf and culm separation, especially in a selection population with large numbers of individuals. However, the reduced contribution of the genetic variance to HI and TIN reinforces the difficulty of genetic gain in the recovery of superior plants. High heritabilities enhance the gains with the selection, by determining the amount of the phenotype that has the participation of the genetic and environmental effects, which is essential for the definition of the best experimental arrangement and the selection pressure to be defined in the research condition (Assis et al., 2010). It is worth noting that heritability directly participates in the prediction of genetic gain regardless of the selection method and, consequently, in the decision-making of the breeding process (Ramalho et al., 2012). Carvalho et al. (2001) discussed that the traits that are determined in a short period of time are those less subject to environmental effects and, therefore, would present the highest heritabilities, not corroborating with the results observed in this study, since both LDM and TDM are produced in almost the whole forage production cycle. However, because they are apomictic clones, there is a tendency to homeostasis, raising, thus, the heritabilities (Cavalcanti et al., 2003). In addition, because of the apomixis in Paspalum, the recombination from the sexual parent in the formation of new individuals can increase the number of alleles in heterozygosity in the F1 clone, maximizing the benefits of hybrid vigor and bringing greater stability to phenotype expression. Resende et al. (2004) analyzed several Panicum maximum hybrids and obtained 
heritabilities for TDM and LDM similar to this study. Similar results were also reported for elephantgrass (Assis et al., 2010) and Brachiaria brizantha (Basso et al., 2009). Nonetheless, Daher et al. (2004) found high heritability for the leaf:culm ratio and lower for total dry matter production. According to Souza Sobrinho et al. (2005), the leaf:culm ratio expresses the variations in the proportion between leaf blade and culm, which is very important for the selection of grazing-tolerant genotypes. However, in spite of reduced heritabilities of LCR, TIN and $\mathrm{HI}$, the results may vary according to the population evaluated, estimation method, unit and experimental precision, without meaning that the results could be definitively extrapolated to other environments or populations (Blank et al., 2010; Borges et al., 2011).

Regarding the correlation between the variables, a high association of LDM with TDM was found in Eldorado do Sul, indicating that the selection pressure for production of total or leaf dry matter influences positively the simultaneous increase of these traits (Table 2). Additionally, the selection pressure on LDM, which is the main trait for selection in forage species, besides the TDM, can also be increased indirectly via CDM, LCR and HI. The positive correlation of TIN with TDM stands out, however, the indirect selection via TIN did not increase leaf production, but increased culm production. In Augusto Pestana, similar correlations were also obtained, characterizing LDM as having the greatest magnitude in the direct and positive relationship with TDM. In addition, CDM also provided a satisfactory fitting of positive association with total dry matter, although being of more difficult estimation. In this environment, the associations between CDM, LCR and HI even of medium to low values were also efficient in the indirect and positive selection on LDM. On the other hand, an inverse correlation was found between TIN and TDM, indicating that the selection pressure for increasing TDM, which has a positive effect on leaf production, tends to reduce tiller number per area, in opposition to that found in Eldorado do Sul and showing that the association between the traits is also based on the genotype by environment interaction (Table 2). It is noteworthy that $\mathrm{HI}$ in the two study locations showed a high positive correlation with LCR, which is an interesting association because in these two environments, there is a positive relationship with LDM. To find greater effectiveness in this species' associations, an overall correlation was also performed, involving simultaneously the cumulative effects of years, genotypes and locations (Table 2), according to Kruger et al. (2011), seeking greater reliability in the study of correlations. In this condition, LDM and

Table 1: Mean squares and genetic parameters for traits of forage interest in apomictic species of the genus Paspalum

\begin{tabular}{|c|c|c|c|c|c|c|c|}
\hline \multirow{2}{*}{ Trait } & \multicolumn{2}{|c|}{ Analysis of Variance } & \multirow{2}{*}{ Mean } & \multicolumn{4}{|c|}{ Genetic parameters } \\
\hline & EMS & TMS & & $\sigma_{\mathrm{P}}$ & $\sigma_{\mathrm{E}}$ & $\sigma_{\mathrm{G}}$ & $\mathbf{h}^{2}$ \\
\hline \multicolumn{8}{|c|}{ Eldorado do Sul (2009/10 + 2010/11) } \\
\hline TDM & 5630810 & $58559901 *$ & 6430 & 14452325 & 5630810 & 8821515 & 0.61 \\
\hline LDM & 1740487 & $37770822 *$ & 4247 & 7745543 & 1740487 & 6005056 & 0.78 \\
\hline CMS & 867248 & $4038609 *$ & 1775 & 1395808 & 867248 & 528560 & 0.38 \\
\hline LCR & 1.58 & $7.67 *$ & 2.62 & 2.60 & 1.58 & 1.02 & 0.39 \\
\hline HI & 0.01 & $0.06^{*}$ & 0.63 & 0.019 & 0.010 & 0.09 & 0.47 \\
\hline TIN & 15369 & $8577^{\text {ns }}$ & 435 & 15369 & 15369 & 0 & - \\
\hline \multicolumn{8}{|c|}{ Augusto Pestana $(2009 / 10+2010 / 11)$} \\
\hline TDM & 5029035 & $56817157 *$ & 6971 & 13660389 & 5029035 & 8631354 & 0.63 \\
\hline LDM & 2764877 & $29263506^{*}$ & 4637 & 7181315 & 2764877 & 4416438 & 0.61 \\
\hline CMS & 527775 & $3637307 *$ & 1842 & 1046030 & 527775 & 518255 & 0.50 \\
\hline LCR & 1.07 & $4.34 *$ & 2.97 & 1.61 & 1.07 & 0.55 & 0.34 \\
\hline HI & 0.01 & $0.01 *$ & 0.65 & 0.003 & 0.002 & 0.001 & 0.26 \\
\hline TIN & 40652 & $98440 *$ & 700 & 21993 & 16694 & 9631 & 0.19 \\
\hline \multicolumn{8}{|c|}{ Geral (Eldorado do Sul + Augusto Pestana + 2009/10 + 2010/11) } \\
\hline TDM & 5347084 & $109858365^{*}$ & 6700 & 22765631 & 5347084 & 17418547 & 0.77 \\
\hline LDM & 2296727 & $64297147 *$ & 4442 & 12630130 & 2296727 & 10333403 & 0.82 \\
\hline CMS & 691164 & $7048231 *$ & 1808 & 1750675 & 691164 & 1059511 & 0.61 \\
\hline LCR & 1.31 & $10.85^{*}$ & 2.79 & 2.90 & 1.31 & 1.59 & 0.55 \\
\hline HI & 0.01 & $0.04^{*}$ & 0.64 & 0.02 & 0.01 & 0.01 & 0.33 \\
\hline TIN & 16694 & $48489 *$ & 576 & 21993 & 16694 & 5299 & 0.24 \\
\hline
\end{tabular}

*Significant at $5 \%$ probability; TDM = Total Dry Matter $\left(\mathrm{kg} \mathrm{ha}^{-1}\right) ; \mathrm{LDM}=$ Leaf Dry matter $\left(\mathrm{kg} \mathrm{ha}^{-1}\right)$; CDM = Culm Dry Matter $\left(\mathrm{kg} \mathrm{ha}^{-1}\right)$; LCR = Leaf:Culm Ratio $(\mathrm{LDM} / \mathrm{CDM}) ; \mathrm{HI}=$ Harvest Index $(\mathrm{LDM} / \mathrm{TDM}) ; \mathrm{TIN}=$ Tiller Number $\left(\mathrm{m}^{2}\right)$; MSE = mean square of error; MST = mean square of treatment; $\sigma_{\mathrm{P}}=$ phenotypic variance; $\sigma_{\mathrm{E}}=$ environment variance; $\sigma_{\mathrm{G}}=$ genetic variance; $\mathrm{h}^{2}=$ heritability. 
CDM form a high positive correlation for incrementing TDM and the use of indirect selection via LCR could help to increase LDM by reducing CDM. As in other conditions, it is possible to use the $\mathrm{HI}$ for indirect and positive selection on LCR. In addition, TIN showed positive association of reduced magnitude in the increase of LCR and CI. Nevertheless, the genetic gains for TDM and LDM in Paspalum improvement are proven efficient and correlated with each other in the simultaneous selection for both characters. Furthermore, LCR and HI bring more effective and positive benefits to LDM than to TDM, but of smaller magnitude of association and greater difficulty in trait evaluation. The indirect selection would be more effective when the correlation between the two traits was high and positive and the heritability of the secondary trait was greater than that of the main trait of interest (DePauw et al., 2007). Assis et al. (2010) affirmed that selection is more effective when it is on high-heritability traits that have direct association with the trait of greater importance. An indirect trait with high heritability may provide genetic progress faster than the direct selection on a main trait, especially when the main trait shows low heritability and is difficult to measure (Carvalho et al., 2001).

In Brachiaria, Borges et al. (2011) also observed a strong correlation of total dry matter with leaf dry matter and culm dry matter. Basso et al. (2009) also detected strong associations between TDM and LDM of Paspalum in the different study locations. Several authors reported that tiller number influences the total dry matter production (Alexandrino et al., 2005; Silva et al., 2008). However, in this study, this parameter had little importance for selection, showing reduced heritability and associations that compromise TDM and LDM. This trend was also observed by Silva et al. (2008) for different species of the genus Pennisetum. These authors argued that the water stress occurred in certain cuts increased the tiller density, but without leaf expansion. The high correlation between LDM and TDM and the high magnitude of heritability suggest that the estimation of total mass without the estimation of LDM in this species is efficient, which would imply lower cost and less measurement time. This approach would allow the observation of a greater number of Paspalum apomictic recombinants, increasing the chances of identifying superior genotypes for LDM via indirect selection by TDM.

Regarding the direct and indirect effects, considering LDM as the main trait, the high direct correlation in Eldorado do Sul, Augusto Pestana, and Overall enables the indirect selection via TDM to increase leaf production (Table 3). This condition allows the collection and analysis of data for direct evaluation by TDM. On the other hand, we point out the considerable indirect effect via CDM in the conditions tested and the indirect effect of TIN on LDM found in Augusto Pestana. The direct effect of CDM on LDM had a strong contribution, however, of similar indirect participation of TDM on LDM. In the LCR, the direct effect on LDM was also evident, however, in Eldorado do Sul the indirect effect via TDM and HI surpassed the direct effect of altering LDM in a similar way to that occurred in the Overall analysis. Then, in

Table 2: Phenotypic correlation coefficients of traits for forage production on apomictic species of the genus Paspalum

\begin{tabular}{|c|c|c|c|c|c|}
\hline Trait & LDM & CDM & LCR & HI & TIN \\
\hline \multicolumn{6}{|c|}{ Eldorado do Sul $(2009 / 10+2010 / 11)$} \\
\hline TDM & $0.97 *$ & $0.91 *$ & 0.13 & 0.29 & $0.32 *$ \\
\hline LDM & & $0.80 *$ & $0.33^{*}$ & $0.50 *$ & 0.27 \\
\hline CMS & & & -0.22 & 0.01 & $0.34^{*}$ \\
\hline LCR & & & & $0.84 *$ & -0.10 \\
\hline $\mathrm{HI}$ & & & & & -0.13 \\
\hline \multicolumn{6}{|c|}{ Augusto Pestana $(2009 / 10+2010 / 11)$} \\
\hline TDM & $0.93 *$ & $0.71 *$ & 0.28 & 0.17 & $-0.35^{*}$ \\
\hline LDM & & $0.44 *$ & $0.57 *$ & $0.49 *$ & -0.12 \\
\hline CMS & & & $-0.43 *$ & -0.43 & $-0.53 *$ \\
\hline LCR & & & & $0.86^{*}$ & $0.38 *$ \\
\hline $\mathrm{HI}$ & & & & & $0.57 *$ \\
\hline \multicolumn{6}{|c|}{ Overall (Eldorado do Sul + Augusto Pestana + 2009/10 + 2010/11) } \\
\hline TDM & $0.95 *$ & $0.82 *$ & 0.14 & 0.17 & -0.03 \\
\hline LDM & & $0.64 *$ & $0.47 *$ & $0.50 *$ & 0.05 \\
\hline CMS & & & $-0.31 *$ & -0.19 & -0.12 \\
\hline LCR & & & & $0.85^{*}$ & $0.24^{*}$ \\
\hline HI & & & & & $0.29 *$ \\
\hline
\end{tabular}

* Significant by the $t$ test at 5\% probability; TDM = Total Dry Matter $\left(\mathrm{kg} \mathrm{ha}^{-1}\right)$; LDM $=$ Leaf Dry matter $\left(\mathrm{kg}\right.$ ha $\left.{ }^{-1}\right)$; CDM $=$ Culm Dry Matter $\left(\mathrm{kg} \mathrm{ha}^{-1}\right) ; \mathrm{LCR}=$ Leaf:Culm Ratio $(\mathrm{LDM} / \mathrm{CDM}) ; \mathrm{HI}=$ Harvest Index $(\mathrm{LDM} / \mathrm{TDM}) ; \mathrm{TIN}=$ Tiller Number $\left(\mathrm{m}^{2}\right)$. 
Augusto Pestana, the effect of LCR on LDM became effective via TIN. Regarding HI, although the direct effect had a strong participation in LDM, the indirect effect via TDM and LCR showed higher magnitude paths on the expression of LDM in Eldorado do Sul and in the Overall analysis. Nevertheless, the indirect effect via CDM and LCR was more effective in Augusto Pestana. Furthermore, for TIN, the indirect effect via TDM was shown effective in all conditions. It is noteworthy that in Augusto Pestana and in the Overall analysis, negative indirect effects via TDM and CDM were more evident in reducing the TIN expression. In Brachiaria, the path analysis showed a marked direct effect of fresh matter weight on total dry matter, suggesting a selection pressure via fresh matter for the identification of superior genotypes for the total dry matter (Borges et al., 2011). Silva et al. (2008) observed that the leaf:culm ratio in accessions of the genus Pennisetum provided one of the smallest direct effects on total dry matter and no positive indirect influence on other traits of forage interest, except tiller number. The authors also identified a negative correlation of this variable with dry matter production, showing disadvantages in the selection via this ratio and contradicting other studies that identified a positive association of leaf:culm ratio with total dry matter production (Brâncio et al., 2003, Alexandrino et al., 2005).

The results indicated that TDM provides along the direct and indirect effects the greatest participation, qualifying the indirect selection for increasing LDM in the apomictic accesses of Paspalum tested. For this

Table 3: Direct and indirect effects of forage traits on leaf dry matter production in apomictic species of the genus Paspalum

\begin{tabular}{|c|c|c|c|c|}
\hline \multirow[b]{2}{*}{ Variable } & \multirow[b]{2}{*}{ Effect } & \multicolumn{3}{|c|}{ Path Analysis } \\
\hline & & $\begin{array}{c}\text { Eldorado do Sul } \\
\text { (ES) }\end{array}$ & $\begin{array}{c}\text { AugustoPestana } \\
\text { (AP) }\end{array}$ & $\begin{array}{c}\text { Overall } \\
(\mathrm{ES}+\mathrm{AP}+\mathbf{2 0 0 9 / 1 0 + 2 0 1 0 / 1 1 )}\end{array}$ \\
\hline \multirow[t]{6}{*}{ TDM } & Direct on LDM & 0.385 & 0.397 & 0.359 \\
\hline & Indirect via CDM & 0.299 & 0.275 & 0.300 \\
\hline & Indirect via LCR & 0.112 & 0.034 & 0.075 \\
\hline & Indirect via HI & 0.161 & -0.002 & 0.076 \\
\hline & Indirect via TIN & -0.015 & 0.244 & 0.140 \\
\hline & r (LDM x TDM) & 0.98 & 0.99 & 0.98 \\
\hline \multirow{6}{*}{$\overline{\mathrm{CDM}}$} & Direct on LDM & 0.335 & 0.304 & 0.332 \\
\hline & Indirect via TDM & 0.344 & 0.359 & 0.324 \\
\hline & Indirect via LCR & 0.030 & -0.030 & 0.003 \\
\hline & Indirect via HI & 0.067 & -0.025 & 0.022 \\
\hline & Indirect via TIN & -0.014 & 0.202 & 0.114 \\
\hline & r (LDM x CDM) & 0.80 & 0.84 & 0.83 \\
\hline \multirow[t]{6}{*}{ LCR } & Direct on LDM & 0.195 & 0.149 & 0.171 \\
\hline & Indirect via TDM & 0.221 & 0.090 & 0.158 \\
\hline & Indirect via CDM & 0.052 & -0.061 & 0.006 \\
\hline & Indirect via HI & 0.236 & 0.049 & 0.132 \\
\hline & Indirect via TIN & -0.017 & 0.100 & 0.077 \\
\hline & r (LDM x LCR) & 0.70 & 0.34 & 0.56 \\
\hline \multirow[t]{6}{*}{$\overline{\mathrm{HI}}$} & Direct on LDM & 0.252 & 0.065 & 0.148 \\
\hline & Indirect via TDM & 0.246 & -0.012 & 0.185 \\
\hline & Indirect via CDM & 0.089 & -0.117 & 0.050 \\
\hline & Indirect via LCR & 0.183 & 0.114 & 0.152 \\
\hline & Indirect via TIN & -0.023 & 0.038 & 0.084 \\
\hline & r (LDM x HI) & 0.77 & 0.09 & 0.63 \\
\hline \multirow[t]{6}{*}{$\overline{\mathrm{TIN}}$} & Direct on LDM & -0.051 & -0.256 & -0.159 \\
\hline & Indirect via TDM & 0.118 & -0.379 & -0.317 \\
\hline & Indirect via CDM & 0.092 & -0.240 & -0.239 \\
\hline & Indirect via LCR & 0.067 & -0.058 & -0.083 \\
\hline & Indirect via HI & 0.114 & -0.009 & -0.078 \\
\hline & r (LDM x TIN) & 0.33 & -0.97 & -0.89 \\
\hline$\overline{\mathrm{R}^{2}}$ & & 0.96 & 0.95 & 0.96 \\
\hline $\mathrm{k}$ & & 0.100220 & 0.102126 & 0.100220 \\
\hline
\end{tabular}

TDM = Total Dry Matter $\left(\mathrm{kg} \mathrm{ha}^{-1}\right) ; \mathrm{LDM}=$ Leaf Dry matter $\left(\mathrm{kg} \mathrm{ha}^{-1}\right) ; \mathrm{CDM}=$ Culm Dry Matter $\left(\mathrm{kg} \mathrm{ha}^{-1}\right) ; \mathrm{LCR}=$ Leaf:Culm Ratio (LDM/ $\mathrm{CDM}) ; \mathrm{HI}=$ Harvest Index $(\mathrm{LDM} / \mathrm{TDM})$; TIN $=$ Tiller Number $\left(\mathrm{m}^{2}\right) ; \mathrm{r}=$ correlation; $\mathrm{R}^{2}=$ Coefficient of determination. 
reason, it emphasizes the importance of path analysis through decomposition of correlations, providing greater safety at choosing the most promising traits for analysis and selection (Montardo et al., 2003). The coefficients of determination were high, indicating that the changes in the dependent variable are almost totally explained by the changes in the explanatory variables.

\section{CONCLUSIONS}

In the apomictic accesses of the genus Paspalum, the increase in the direct selection pressure on the total and leaf dry matter is strengthened by the greater contribution of genetic effects than environmental effects to the phenotypic variance composition.

Genetic gain in leaf production is efficient via indirect selection by total dry matter, which is a high-heritability trait and of easier selection and measurement.

\section{ACKNOWLEDGEMENTS}

The authors want to thank CNPq, CAPES and Sulpasto for the financial support and the scholarships for scientific initiation, technical assistance, postgraduation and research productivity.

\section{REFERENCES}

Acuña CA, Blount AR, Quesenberry KH, Kenworthy KE \& Hanna WW (2009) Bahiagrass tetraploid germplasm: reproductive and agronomic characterization of segregating progeny. Crop Science, 49:581-588

Aguilera PM, Sartor ME, Galdeano F, Espinoza F \& Quarín CL (2011) Interspecific tetraploid hybrids between two forage grass species: sexual Paspalum plicatulum and apomictic $P$. guenoarum. Crop Science, 51:1544-1550.

Alexandrino E, Gomide JA \& Gomide CAM (2005) Crescimento e desenvolvimento do dossel de Panicum maximum $\mathrm{Cv}$ Mombaça. Revista Brasileira de Zootecnia, 34:2164-2173.

Assis LCSLC, Lira MA, Santos MVF, Dubeux Júnior CB \& Cunha MV (2010) Estimativa de parâmetros genéticos sob duas estratégias de avaliação em híbridos intra e interespecíficos de capim-elefante. Revista Brasileira de Zootecnia, 39:2589-2597.

Basso KC, Resende RMS, Valle CB, Gonçalves MC \& Lempp B (2009) Avaliação de acessos de Brachiaria brizantha Stapf e estimativas de parâmetros genéticos para caracteres agronômicos. Acta Scientiarum Agronomy, 31:17-22.

Benin G, Olegario GS, Pagliosa ES, Lemes C, Signorini A, Beche E \& Capelin MA (2009) Capacidade de combinação em genótipos de trigo estimada por meio de análise multivariada. Pesquisa Agropecuária Brasileira, 44:1145-1151.

Blank AF, Souza EM, Paula JWA \& Alves PB (2010) Comportamento fenológico e genotípico de populações de manjericão. Horticultura Brasileira, 28:305-310.

Borges V, Sobrinho FS, Ledo FJS \& Kopp MM (2011) Associação entre caracteres e análise de trilha na seleção de progênies de meios-irmãos de Brachiaria ruziziensis. Revista Ceres, 58:765772 .
Brâncio PA, Nascimento Junior D, Euclides VPB, Fonseca DM, Almeida RG, Macedo MCM \& Barbosa RM (2003) Avaliação de três cultivares de "Panicum maximum" Jacq sob pastejo: Composição da dieta, consumo de matéria seca e ganho de peso animal. Revista Brasileira de Zootecnia, 32:1037-1044.

Cavalcanti JJV, Crisóstomo JR, Barros LM \& Paiva JR (2003) Heterose em cajueiro anão precoce. Ciência Agrotecnica, $27: 565-570$

Carvalho FIF, Silva SAS, Kurek AJ \& Marchioro VS (2001) Estimativas e implicações da herdabilidade como estratégia de seleção. Pelotas, UFPel. 99p.

Cruz CD (2006) Programa Genes: Estatistica experimental e matrizes. Viçosa, UFV. 285p.

Cruz CD, Regazzi AJ \& Carneiro PCS (2004) Modelos biométricos aplicados ao melhoramento genético. $3^{\mathrm{a}}$ ed. Viçosa, UFV. 480p.

Coimbra JLM, Benin G, Vieira EA, Oliveira AC, Carvalho FIF, Guidolin AF \& Soares AP (2005) Conseqüências da multicolinearidade sobre a análise de trilha em canola. Ciência Rural, 35:347-352.

Daher RF, Pereira AV, Pereira MG, Lédo FJS, Amaral Junior AT, Rocabado JMA, Ferreira CF \& Tardin FD (2004) Análise de trilha de caracteres forrageiros do capim-efefante (Pennisetum purpureum Schum). Ciência Rural, 34:1531-1535.

DePauw RM, Knox FE, Clarke FR, Wang H, Fernandez MR, Clarke JM \& McCaig TN (2007) Shifting undesirable correlations. Euphytica, 157:409-415.

Daurelio LD, Espinoza F, Quarin CL \& Pessino SC (2014) Genetic diversity in sexual diploid and apomictic tetraploid populations of Paspalum notatum situated in sympatry or allopatry. Plant Systematics and Evolution, 244:189-199.

Falconer DS \& Mackay TFC (1996) Introduction to quantitative genetics. $4^{\mathrm{a}}$ ed. London, Longman. 463p.

Galarça SP, Lima CSM, Silveira G \& Rufato AR (2010) Correlação de Person e Análise de trilha identificando variáveis para caracterizar porta enxerto de Pyrus communis L. Ciência e Agrotecnologia, 34:860-869.

Krüger CAMB, Silva JAG, Medeiros SLP, Dalmago GA \& Gaviraghi J (2011) Herdabilidade e correlação fenotípica de caracteres relacionados à produtividade de grãos e à morfologia da canola. Pesquisa Agropecuária Brasileira, 46:1625-1632.

Lopez RR \& Franke LB (2011) Correlação e análise do coeficiente de trilha dos componentes do rendimento de sementes de grama-forquilha. Revista Brasileira de Zootecnia, 40:972-977.

Montardo DP, Dall'agnol M, Crusius AF \& Paim NR (2003) Análise de trilha para rendimento de sementes de trevo vermelho (Trifolium pratense L). Revista Brasileira de Zootecnia, 32:1076-1082.

Montgomery DC \& Peck EA (2001) Introduction to linear regression analysis. $3^{\mathrm{a}}$ ed New York, John Wiley \& Sons. 504p.

Nabinger C, Ferreira ET, Freitas AK, Carvalho PCF \& Sant'anna DM (2009) Produção animal com base no campo nativo: aplicações de resultados de pesquisa. In: Pillar VD, Müller SC, Castilhos ZMS \& Jacques AVA (Eds.) Campos Sulinos: Conservação e Uso Sustentável da Biodiversidade. Brasília, Ministério do Meio Ambiente. p.175-198.

Pereira EA, Barros T, Volkmann GK, Battisti GK, Silva JAG, Simoni C \& Dall'Agnol M (2012) Variabilidade genética de caracteres forrageiros em Paspalum. Pesquisa Agropecuária Brasileira, 47:1678-1540.

Pereira EA, Dall'agnol M, Nabinger C, Huber KGC, Montardo DP \& Genro TCM (2011) Produção agronômica de uma coleção de acessos de Paspalum lepton Parodi. Revista Brasileira de Zootecnia, 40:498-508. 
Reis CAO, Schifino-Wittmann MT \& Dall’Agnol M (2008) Cytogenetic characterization of a collection of Paspalum nicorae Parodi accessions. Crop Breeding and Applied Biotechnology, 8:212-218.

Ramalho MAP, Abreu AFB, Santos JB \& Nunes JAR (2012) Aplicações da genética quantitativa no melhoramento de plantas autógamas. Lavras, UFLA. 522p.

Resende RMS, Jank L, Valle CB \& Bonato ALV (2004) Biometrical analysis and selection of tetraploid progenies of Panicum maximum using mixed model methods. Pesquisa Agropecuária Brasileira, 39:335-341.

Silva MA, Lira MA, Santos MVF, Junior JBCD, Cunha MV \& Freitas MV (2008) Análise de trilha em caracteres produtivos de Pennisetum sob corte em Itambé, Pernambuco. Revista Brasileira de Zootecnia, 37:1185-1191.
Souza Sobrinho F, Pereira AV, Ledo FJS, Botrel MA, Oliveira JS \& Xavier DF (2005) Avaliação agronômica de híbridos interespecíficos entre capim-elefante e milheto. Pesquisa Agropecuária Brasileira, 40:873-880.

Streck EV, Kämpf N, Dalmolin RSD, Klamt E, Nascimento PC, Scneider P, Giasson E \& Pinto LFS (2008) Solos do Rio Grande do Sul. Porto Alegre, Emater/UFRGS. 222p.

Steel RGD \& Torrie JL (1980) Principles and procedures of statistics. New York, McGraw-Hill. 418p.

Valle CB, Jank L \& Resende RMS (2009) O melhoramento de forrageiras tropicais no Brasil. Revista Ceres, 56:460-472. 